\title{
Uma revista científica em movimento
}

O Jornal Brasileiro de Patologia e Medicina Laboratorial (JBPML), em sendo o veículo oficial de comunicação científica de três sociedades de especialistas, está permanentemente atento a requisitos, como tempo para análise dos manuscritos, resposta aos autores e publicação, para tornar-se, cada vez mais, um importante canal de transmissão do conhecimento gerado no ambiente de pesquisa médica brasileiro.

Apoiado por um corpo editorial experiente, por comissões editoriais especializadas, constituídas por pares científicos, todos pesquisadores eminentes e profícuos, bem como por uma estrutura administrativa e gráfica competente, o JBPML tem se caracterizado como uma revista médica dinâmica e pronta a movimentar-se em direção a atender exigências cada vez mais extensas, quer dos pesquisadores, quer do seu público leitor.

A recente indexação ao SciELO, que tornará possíveis a consulta e a leitura integral, pela Internet, dos manuscritos publicados pelo JBPML já provoca necessidades de adaptação. Os autores de artigos encaminhados para publicação têm-se mostrado atentos ao tempo necessário à análise de seus trabalhos e à sua conseqüente divulgação. Podemos acrescentar, não sem uma agradável sensação de estar caminhando na direção correta, que o ritmo de chegada de artigos para avaliação tornou-se constante e cresce em volume. Desta forma, a tendência seria o aumento no tempo de espera para avaliação e publicação.

A solução encontrada para atender a esta demanda foi elevar a quantidade de trabalhos publicados por número da revista, com sensível redução no tempo de resposta aos autores.

A atividade de pesquisa médica brasileira cresce em ritmo intenso, apoiada por instituições autônomas de fomento e, mais recentemente, com a iniciativa privada mostrando sinais de que o seu interesse neste tipo de investimento pode tornar-se uma constante. É de fundamental importância que se disponha de veículos respeitados pela comunidade acadêmica para escoamento da informação científica originada nos centros de investigação brasileiros.

O JBPML apresenta-se como um destes veículos, apto a tornar-se um órgão de comunicação científica eficiente, cumprindo a missão de atender às expectativa dos pesquisadores que nos confiam seus trabalhos para publicação.

\footnotetext{
Álvaro Rodrigues Martins

Médico Patologista Clínico Diretor Científico da SBPC/ML
} 